\title{
Enteral yeast-selenium supplementation in preterm infants
}

\author{
Gábor Bogye, Georg Alfthan, Tamás Machay, László Zubovics
}

\begin{abstract}
Aim-To study the bioavailability of selenium enriched yeast in preterm infants living in a low selenium area (Hungary). Methods-Thirty six preterm infants were randomly assigned to two groups at birth with respect to selenium supplementation. In the supplemented group $(n=18)$ infants received $4.8 \mathrm{mg}$ of selenium enriched yeast containing $5 \mu \mathrm{g}$ selenium daily.

Results-In the supplemented group the serum selenium concentration increased from $36.1( \pm 12.8) \mu \mathrm{g} / 1$ to $43.5(7.9) \mu \mathrm{g} / 1$ and in the non-supplemented group it decreased from $34.4(20.4) \mu \mathrm{g} / 1$ to 26.1 (16.6) $\mu \mathrm{g} / \mathbf{1}$ from birth in two weeks. No complications or side effects as a result of supplementation were observed.

Conclusions-Selenium enriched yeast is a safe and an effective form of short term enteral selenium supplementation for preterm infants.

(Arch Dis Child Fetal Neonatal Ed 1998;78:F225-F226)
\end{abstract}

Keywords: selenium; deficiency; supplementation; preterm infant

Pathogenesis of some neonatal diseases may be associated with selenium deficiency, such as retinopathy of prematurity and bronchopulmonary dysplasia, but our knowledge about the adequate form and dose of selenium supplementation for preterm infants is still limited. ${ }^{12}$ There are no published data on the possible impacts and side effects of yeast-selenium for infants, although its bioavailability is higher than for other selenium compounds in adults. ${ }^{3}$ This study aimed to assess the bioavailability of selenium enriched yeast in preterm infants living in a low selenium area (Hungary). ${ }^{4}$

Nutrition Laboratory, National Public Health Institute of Finland, Helsinki, Finland G Alfthan

1st Department of Obstetrics and Gynecology, Perinatal Intensive Centre, Semmelwies Medical School, Budapest, Hungary

T Machay

Perinatal Intensive Care, Schöpf-Mérei Ágost Hospital, Budapest, Hungary L Zubovics

Correspondence to: Dr Gábor Bogye, 1027 Budapest, Frankel Leó u. 7., Hungary.

Accepted 26 November 1997 istics of the two groups of infants were similar and there were no clinically significant differences between the enteral and parenteral regiments of the two groups. Serum samples were obtained from blood collected for normal clinical management of the infants one and 14 days after birth. Blood in excess of laboratory requirements was used for this study and no blood samples were taken expressly for the study. Our investigation was approved by the ethical committee of the participating institutes.

Selenium was determined using an electrothermal atomic absorption spectrophotometric method with nickel nitrate and nitric acid as matrix modifiers. ${ }^{5}$ The precision of the method between series $(n=10)$ for two serum pools $65.3 \mu \mathrm{g} / 1$ and $78.3 \mu \mathrm{g} / 1$ were $3.5 \mathrm{CV} \%$ and 3.1 $\mathrm{CV} \%$, respectively. The accuracy was verified by analysing an external reference serum, $\mathrm{SN}$ 112 (Nycomed Co, Oslo, Norway, recommended value $90 \mu \mathrm{g} / \mathrm{l})$, which gave the result $90.8(2.0) \mu \mathrm{g} / \mathrm{l}(\mathrm{n}=5)$. The detection limit of the method for serum is $4.5 \mu \mathrm{g} / \mathrm{l}$.

The effect of treatment with selenium within groups was compared using the paired $t$ test (SAS statistical program for VAX computers).

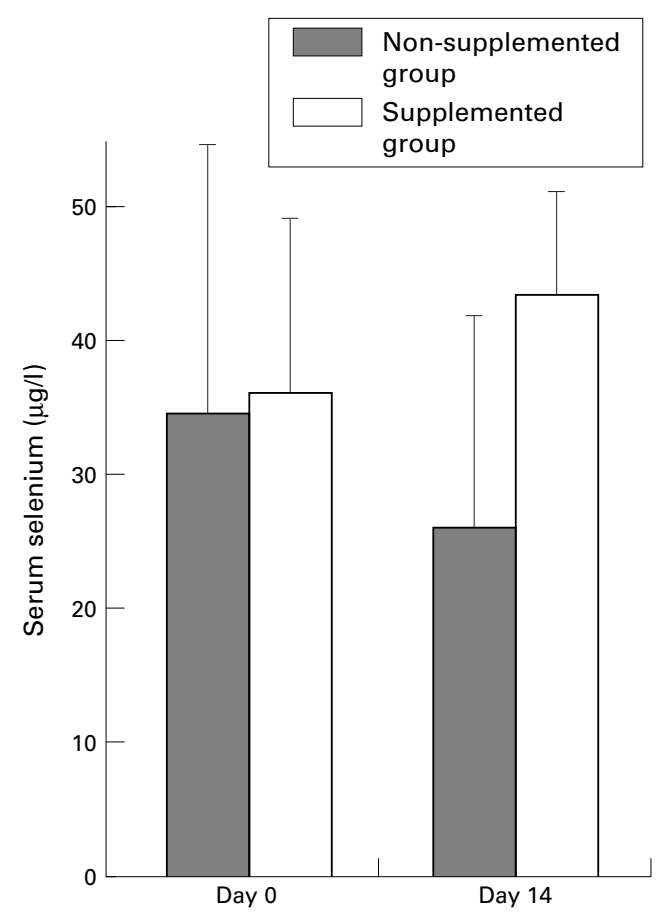

Figure 1 Changes in mean (SD) selenium concentration of the $5 \mu \mathrm{g} /$ day selenium supplemented and non-supplemented groups of preterm infants during the first 14 days of life. 


\section{Results}

The changes in serum selenium concentration of the non-supplemented and supplemented groups during the first 14 postnatal days are shown in fig 1 . The non-supplemented group's mean (SD) serum selenium concentration decreased significantly in 2 weeks $(\mathrm{p}<0.005)$ from 34.4 (20.4) $\mu \mathrm{g} / 1$ to 26.1 (16.6) $\mu \mathrm{g} / 1$. There was a significant increase in the serum selenium concentration of the infants given enteral selenium supplementation $(\mathrm{p}<0.01)$. The mean (SD) value increased from 36.1 (12.8) $\mu \mathrm{g} / \mathrm{l}$ to $43.5(7.9) \mu \mathrm{g} / \mathrm{l}$. We $\mathrm{did}$ not observe any complications or side effects as a result of enteral yeast-selenium supplementation.

\section{Discussion}

Serum selenium concentrations equilibrate within a few days, responding rapidly to major changes in intake. Therefore, serum selenium measurements should reflect changes in selenium status during rapid growth and development more effectively than other parameters. ${ }^{2}$ In our investigation the serum selenium concentrations of the non-supplemented preterm infants decreased significantly within two weeks of birth. Other studies of infants whose selenium intake was considered to be adequate showed increases in serum selenium concentrations after birth, ${ }^{6}$ so a decrease in selenium does not seem to be physiological.

In conclusion, we report that short term selenium supplementation of $5 \mu \mathrm{g} /$ day in the form of yeast-selenium significantly increased the serum selenium concentration of premature infants without any obvious side effects. We propose that yeast-selenium is a safe and an effective means of short term enteral selenium supplementation in preterm infants.

We thank Dr Gábor Tompos for statistical advice. This work was supported by OTKA (F-0222/96).

1 Daniels L, Gibson R, Simmer K. Randomised clinical trial of parenteral selenium supplementation in preterm infants. Arch Dis Child 1996;74:F158-64.

2 Litov R E, Combs G F. Selenium in pediatric nutrition. Pediatrics 1991;87:339-51.

3 Alfthan G, Aro A, Arvilommi H, Huttunen J K. Selenium metabolism and platelet glutathione peroxidase activity in healthy Finnish men: effect of selenium yeast, selenite and selenate supplementation. Am f Clin Nutr 1991;53:120-5.

4 Alfthan G, Bogye G, Aro A, Feher J. The human selenium status in Hungary. $\mathcal{F}$ Trace Elem Electrolytes Health Dis 1992;6:233-8.

5 Alfthan G, Kumpulainen J. Determination of selenium in small volumes of blood plasma and serum by electrothermal atomic absorption spectrometry. Anal Chim Acta mal atomic absorp

6 Kumpulainen J, Salmenperä L, Siimes M A, Koivistoinen P, Lehto P, Perheentupa J. Formula feeding results in lower selenium status than breast-feeding or selenuium supplemented formula feeding: a longitudinal study. Am $\mathcal{F}$ Clin Nutr 1987;45:49-53. 